\title{
Kampung Aur Slum Settlement and Relocation Reluctance
}

\author{
Novida Yenny ${ }^{1}$, Rohani ${ }^{2}$, Kamarlin Pinem ${ }^{3}$, Nabila Anggraini ${ }^{4}$, Yemima Utami Harianja ${ }^{5}$ \\ \{novidayennygeo@gmail.com ${ }^{1}$, rohanispdmi@gmail.com ${ }^{2}$, bregina1955@yahoo.com ${ }^{3}$ \} \\ Geography Department, Faculty of Social Sciences, Universitas Negeri Medan, Indonesia
}

\begin{abstract}
KampungAur settlement is one of the slums of 18 villages determined based on Medan Mayor Decree No. 640 / 039.K / I / 2015, with a very poor slum level, 3.49 Ha slum area and 307 households. Location Slums are scattered in various areas in Medan City, including along the riverbanks, along railroads, port areas, industrial areas, trade areas, and border areas of Medan City. The focus of the study was the slums of Aur village, Medan Maimun District and the reluctance of residents to be relocated. The research objectives are; to find out the factors that cause the reluctance of relocation of residents of slums in Aur Village, Aur Village, Medan Maimun District, Medan City. The research method used a qualitative descriptive. The results of research on the reluctance of residents due to relocation of several factors, among others; 1) Settlement that has been passed down from parents has finally become the basis for residents to claim their legal presence in agrarian, 2) the location of KampungAur which is near and downtown such as offices, restaurants and others that are very supportive for the economic activities of citizens, 3 ) the high family ties between residents supported by the same ethnic / ethnic origin, and a sense of shared destiny, 4) basic housing services that are deemed sufficiently adequate such as access to and out of villages, roads that connect between RTs, available clean water facilities, and electricity PLN, 5) there are facilities and infrastructure that can meet the needs of citizens to socialize with each other and strengthen family relationships.
\end{abstract}

Keywords: Slums, Relocation, Reluctance.

\section{Introduction}

According to Law No. 1 Article 1 Paragraph 13 of 2011 concerning housing and settlement areas, explained that slums are settlements that are not livable due to irregularity of buildings, high level of building density, and the quality of buildings and facilities and infrastructure that do not meet the requirements. In short, slum housing is housing that has decreased the quality of its function as a residence [1]. In general, slums in urban areas are in the middle of the city but are hidden from the environment that is usually passed by the general public. This can be in the form of slums or squatter slum areas. So that the slums make the city face environment does not healthy accompanied by poor environmental sanitation. Slums are referred to as illegal settlements if they are on buildings or land that is not owned by the state 
for settlement, such as on the banks of a river, on the banks of a railroad, under a flyover, in city parks and open land other green.

In-Law Number 1 of 2011 concerning Housing and Settlement Areas, it has actually been explained about the prohibition for anyone to make settlements on the equivalent of a railroad track, this is stated in Article 140 which reads: "Everyone is prohibited from building, housing, and/or settlement in a place that could potentially cause danger to goods or people. "means that: what is meant by" places that could potentially cause danger "include, railroad border, under the bridge, the area of Extra High Voltage Airways (SUTET), Regional River Border (DSS), disaster-prone areas, and special areas such as military zones. However, the existence of Law Number 2011 concerning Housing and Settlements has yet to run optimally. The Law has explicitly contained a prohibition on the establishment of settlements that do not have a settlement permit.

Rahmadi (2009), explained that specifically in handling squatters (settlements on illegal land) both in urban and outside urban areas, any building that stands up is recommended to be moved/relocated to a safer location in accordance with the existing spatial plan except construction or facility activities related to irrigation or infrastructure in the public interest [2]. If the eviction is considered as the last solution that must be done, then this effort also has procedures that must be carried out, so that the impact can be minimized. The eviction solution will almost certainly be accompanied by relocation or resettlement efforts. However, until now the relocation efforts that the government intends to do have never been going well. Even though the government already has a strong legal basis for relocation. The powerlessness of the government in dealing with slum communities needs to be questioned. The community seems to have great power that can compete with the power of law, even though the community is positioned as a violator of the law.

Medan city with an area of $265,10 \mathrm{~km}^{2}$ (26510 ha) consists of 21 districts and 151 villages with a total number of 520,343 households and a population of 2,121,053 people (BPS North Sumatra, 2018) [3]. Medan is the 3rd largest city in Indonesia after Jakarta and Surabaya. The residential areas in Medan City are located in the 17 biggest Subdistricts in 48 kelurahan, with a slum area of 628,60 ha or $2.37 \%$ of the area of Medan City (Pinem, 2011) [4]. The location of slums in Medan is on the banks of the river, along the railroad tracks, the port area, the industrial area, the trade area, and the periphery areas. Judging from the distribution of slum locations, the slums should have been relocated or evicted.

Slums, in essence, can be a slum or squatter areas. Cities in Indonesia population growth is not matched by the construction of urban facilities and infrastructure and the improvement of urban services, even what happened was that some urban areas experienced environmental degradation that could potentially create slum areas. As a result, slum areas (slums) appear in several areas of the city and it is unavoidable that it is not planned by the government, but these slum areas (slums) grow naturally. It is different from the definition of squatter areas which means a public area or government property that is not allowed to be inhabited. So the squatter areas are known as wild slums. UN-HABITAT (UN Agency) defines slums as an association and individuals who live under one roof in an urban area that lacks one or more of the following things [5], including: (1) settlements that can survive in extreme climatic condition, (2) adequacy of space in housing, which means no more than 3 people share the same space, (3) easy access to clean water at affordable prices, (4) access to adequate sanitation by 
providing private or public toilets with restrictions on the number of users, and (5) a sense of security of land and building property rights that can prevent residents from forced evictions. According to Rindrojono, (2013) Slums are a general picture of attitudes and low behavior seen from living standards and low income. In other words, slums can be interpreted as signs or a stamp given by the upper class already established to the group bottom which is not yet well established [6].

According to Budiharjo (2011), the characteristics of slums can be caused by housing factors and infrastructure factors. Besides the criteria improvement of slums can be seen from social symptoms and physical symptoms [7], namely (1) slum settlement characteristics including semi-permanent and not permanent housing factors; irregular layout; building status generally does not have a building permit; high density of buildings and population; the condition of the building is unfit for habitation and the distance between buildings is tight; lack of health of the neighborhood, and infrastructure factor (accessibility / road, drainage, clean water, wastewater, and garbage).

The criteria for improvement of slums, namely: (1) social symptom (low social life, very low socioeconomic status, the level of education is very low, and population density is very high), and (2) physical symptoms (the average building condition is below the minimum standard, generally a village with non-permanent and semi-permanent buildings has reached the age of 10 years, high building density, very minimum open space and distance between buildings, the condition of physical facilities is below the minimum standard, areas that are heavily affected by flooding, and regional conditions require regulation in terms of land use).

\section{Research method}

This research was conducted deductively, so researchers departed from theory to go into the field in searching for data which could then be used in examining what factors influence the existence of slum areas in Kampung Aur, Aur Village, Medan Maimun District, Medan City. This study uses a qualitative descriptive approach to analyze existing problems.

The population in this study is the entire population of Kampung Aur, Medan Maimun District, Medan City. The selection of informants with certain social situations, by itself, needs to be done intentionally (not randomly), based on what is known about the situation and conditions in Kampung Aur settlement. The sample used for this study was only 10 respondents. The criteria for informants in this study are people who have lived in the study site for more than 5 years, plus the village head, RT and community leaders and related parties, this shows that the informant is very well aware of the problems and characteristics of the community.

The location of the research was conducted in Kampung Aur Village, Medan Maimun District, Medan, North Sumatra, where settlements were located around the Deli River. The slums are included in the category of squatters areas. The time of the study is about 6 months from starting licensing, research and sampling in the field, to the preparation of the final report. One of the characteristics of qualitative research is humans as tools or instruments (Moleong, 2010) [8]. So to get the data/information done by observation, in-depth interviews, and study documents as supporting research.

The analytical method in this study is to determine the factors that cause the existence of slums by using inductive analysis as the main basis for studying various data obtained based on a 
grounded theory approach. This approach has three basic elements that are interrelated with one another. The process of obtaining a theory is obtained from the flow of concepts, not existing data. While the concept is obtained through existing conceptualization data. On the other hand, the category is the beginning of the process of developing a theory which is higher than the concept. While propositions show the relationship between the concepts of Struss and Corbin (1990) [9].

\section{Result and discussion}

Kampung Aur settlement is a slum area determined by the Mayor of Medan through Decree No.640 / 039.K / I / 205 and this condition can be seen in plain view [10]. The housing conditions that are narrow, close together, with a small size $( \pm 4 \times 6 \mathrm{~m} 2)$ have one room that is inhabited by an average number of family members of more than 4 people and does not meet proper living standards. The existence of Kampung Aur Settlement is a part of the history that continues along with the development of Medan City and the population that lives in Kampung Aur goes on for generations. Kampung Aur located in Medan Maimun District.

Medan Maimun Regency is located near the center of Medan City, consisting of six Kelurahans, there is Kel. Aur, Ex. Hamdan, Ex. Jati, Kel Kampung Baru, Kel Sei Mati, and Kel.Suka Raja, with an area of around 3,342 $\mathrm{km}^{2}$. Kampung Aur has 10 wards, each of which is headed by a circle Head. Kampung Aur settlement is famous in Medan with various problems stored in it. Physically seen as settlements that are not much different from each other, it looks dirty and crowded. This condition is most likely due to the almost equal economic level of the community, which is mostly classified as poor.

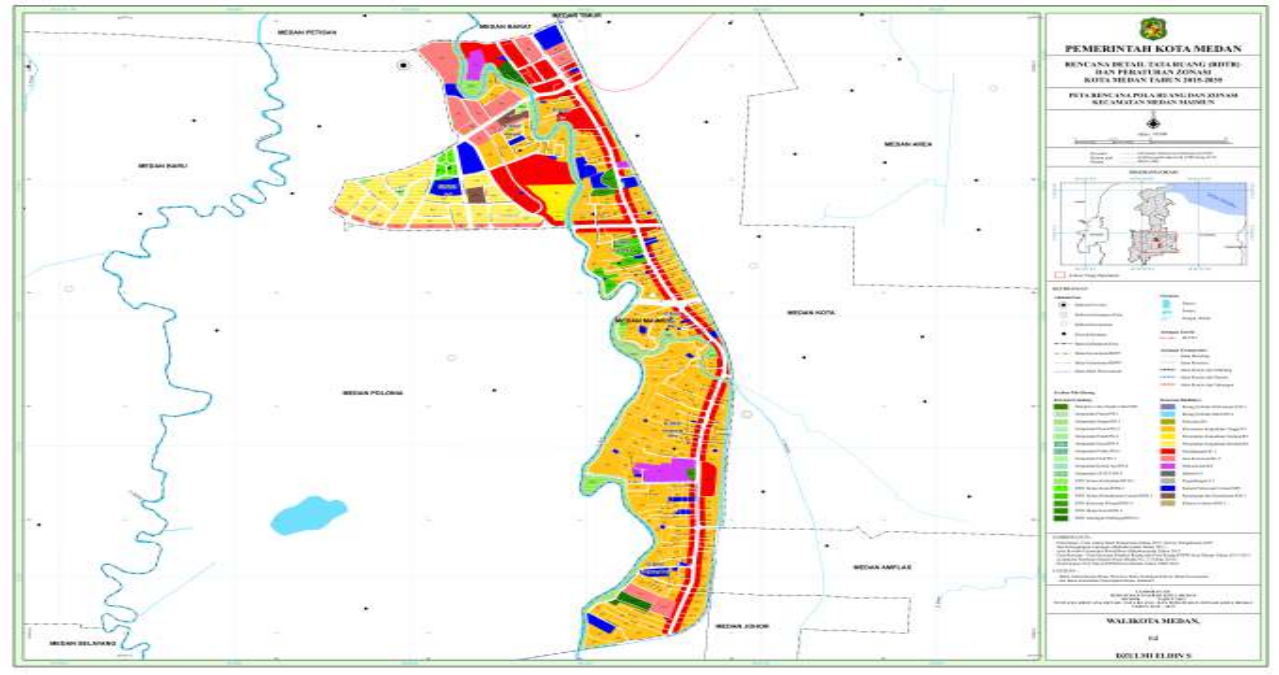

Fig 1. Map of The Maimun Terrain Spatial Plan 
Table 1. Characteristics of Settlement Residents of Kampung Aur

\begin{tabular}{|c|c|c|}
\hline No & $\begin{array}{l}\text { Character of } \\
\text { Settlement }\end{array}$ & Information \\
\hline 1 & Ownership status & $\begin{array}{l}\text { - } 80 \% \text { of those who live on the edge of the river is their } \\
\text { property, with land status without certificates, owned from } \\
\text { generation to generation from parents, }(60 \% \text { occupied by } \\
\text { the owner and } 40 \% \text { leased) } \\
\text { - The } 10 \% \text { located at the top are certified privately owned, } \\
\text { generally of Chinese descent. } \\
\text { - } 65 \% \text { of the people living on the banks of the railroad tracks } \\
\text { are their property without certificates, } 35 \% \text { are tenants }\end{array}$ \\
\hline 2 & House type & $\begin{array}{ll}\text { - } & \text { Permanent house }=15 \% \\
\text { - } & \text { Semi-permanent }=35 \% \\
\text { - } & \text { Emergency house }=50 \%\end{array}$ \\
\hline 3 & House condition & $\begin{array}{l}\text { - } 90 \% \text { of houses located near riverbanks are not suitable for } \\
\text { habitation (house size Lk. } 18 \mathrm{~m}^{2} \text {, average room } 1 \text { plus a } \\
\text { multi-function living room, modest minimum). } \\
\text { - } 95 \% \text { of the houses located on the upper part of the river are } \\
\text { livable. } \\
\text { - } 85 \% \text { of the houses located on the banks of the railroad } \\
\text { uninhabitable }{ }^{(2} \mathrm{Lk} .18 \mathrm{~m} \text { house size, an average of } 1 \text { room } \\
\text { plus a living room multi-functional, sober MCK). }\end{array}$ \\
\hline 4 & Ethnic group & $\begin{array}{l}\text { - } 75 \% \text { of the riverbanks are Minang, } 16 \% \text { Javanese, } 14 \% \\
\text { Malay, etc. } \\
\text { - } 95 \% \text { located at the top of the Deli river are ethnic Chinese. } \\
\text { - } 70 \% \text { of the houses are located on the banks of the Minang } \\
\text { railroad and the rest is a mixture of Java, Malay, Nias, } \\
\text { Batak. }\end{array}$ \\
\hline 5 & Population density & Solid \\
\hline 6 & Green open space & Almost no. \\
\hline
\end{tabular}

Source: Analysis of Primary and Secondary Data, 2019.

Based on the character of the settlement in the table above, most of the houses near the Deli river are self-owned houses that have been owned by parents for generations, with ownership status without certificates and most of them are owned by Minang tribes, with unsuitable living conditions. Likewise, the settlement on the edge of the railroad tracks, it is also legally an illegal settlement whose land ownership is owned by PJKA, but residents make houses with the status of land for rent, and some residents are tenants. Unlike the residents who live in Kampung Aur, which is located at the top of Kampung Aur, bordering Jalan Brigjen Katamso, which is a legal (certified) settlement that is inhabited by most ethnic Chinese. See the Figure below. 


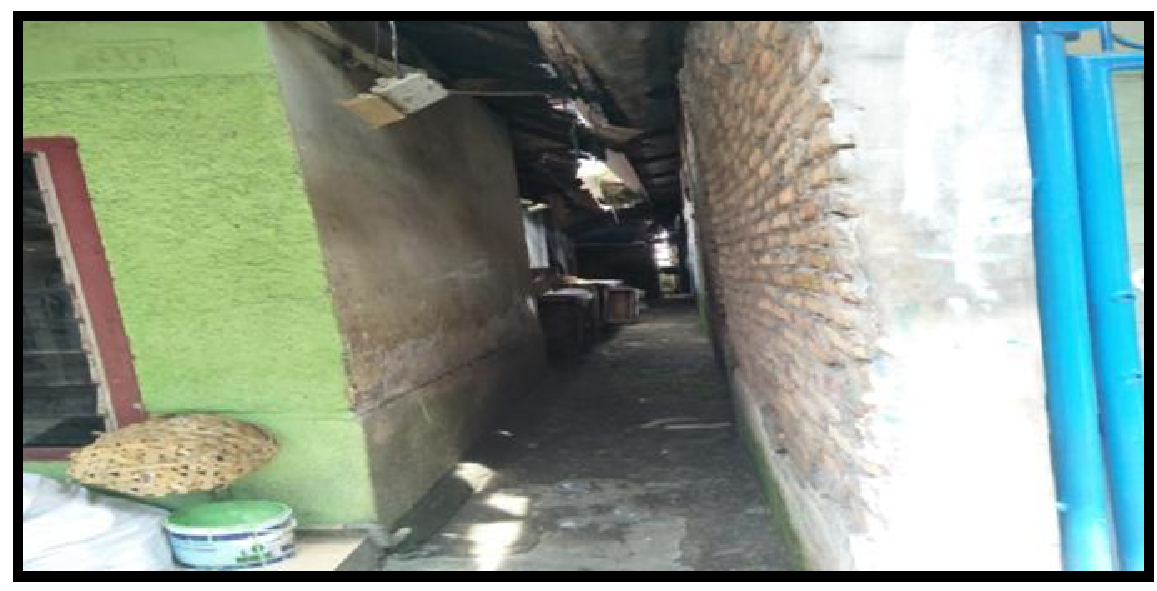

Fig. 2. Narrow alley connecting each house

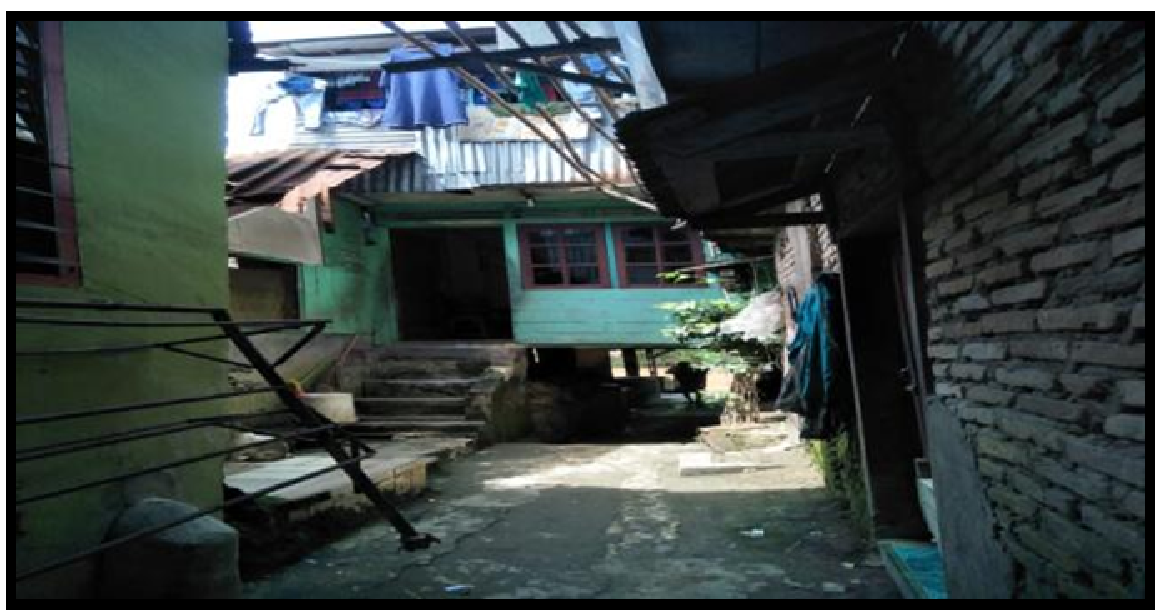

Fig. 3. The layout of residents' homes that are layered and irregular 


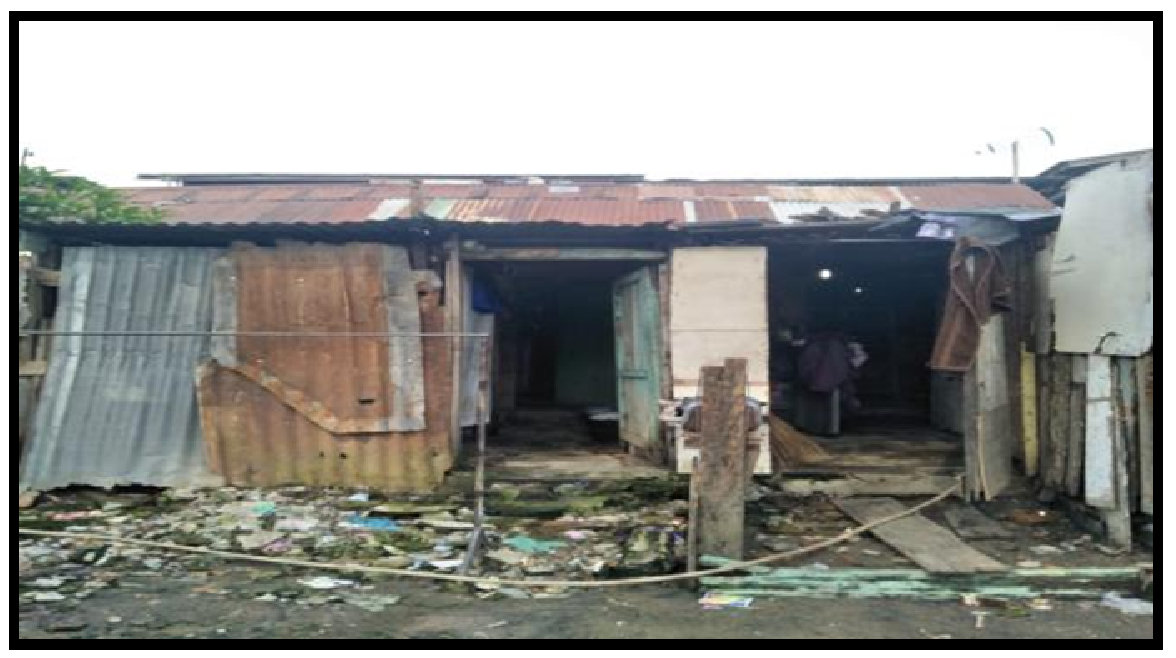

Fig. 4. Conditions behind one of the houses of the residents waste disposal channel

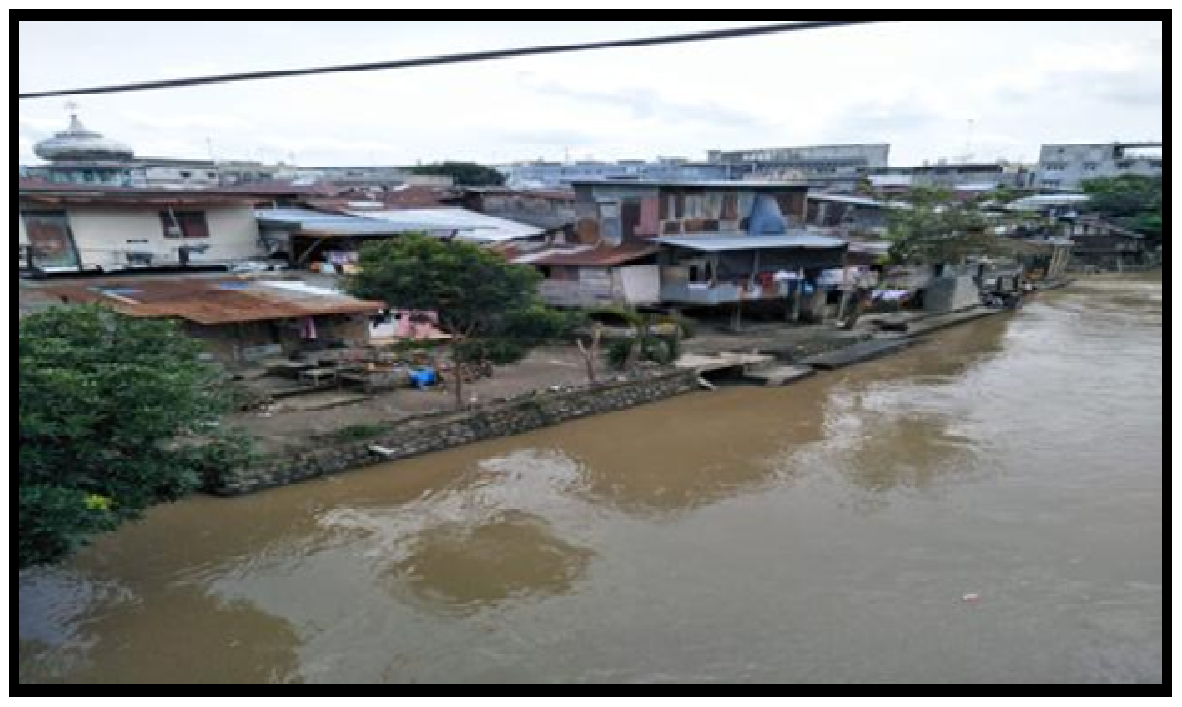

Fig 5. Circle IV view of Aur Village on the Deli River 
The basic services of the Settlement are supporting facilities that complement the Settlement which is at the same time a condition like a Settlement. The basic services of this settlement can are seen in the following table;

Table 2. Basic Settlement Services

\begin{tabular}{|c|c|c|}
\hline No & Criteria & Information \\
\hline 1 & Road condition & $\begin{array}{l}\text { Almost all residential roads, the pavement has been done } \\
\text { with cement (especially the main road which is adjacent } \\
\text { to the mosque). }\end{array}$ \\
\hline 2 & Clean water facilities & $\begin{array}{l}\text { Adequately, PDAM water channels have entered every } \\
\text { resident's home. But to avoid costs large water payments, } \\
\text { in part, great citizens still do MCK activities on the river. }\end{array}$ \\
\hline 3 & Toilet & $\begin{array}{l}\text { All houses have septic tanks and drainage pipes which } \\
\text { leads to the river. }\end{array}$ \\
\hline 4 & Electricity facility & Adequate every day \\
\hline 5 & Waste management & $\begin{array}{l}\text { Inadequate, because not all locations have landfills } \\
\text { still seen scattered on house residents' houses. And there } \\
\text { are still some residents who made the river as a final } \\
\text { dump the rubbish. }\end{array}$ \\
\hline 6 , & Drainage ditch & $\begin{array}{l}\text { The drainage of household wastewater is not good, } \\
\text { because there is no good drainage. }\end{array}$ \\
\hline
\end{tabular}

Source: Secondary Data Analysis, 2019.

The table above shows that the road which is the access of residents between the alleys has not all been hardened, but for roads that connect between environments, hardening has been done with cement. The existence of a road between the alley connecting the Settlement with the river is partly still a dirt road, as well as the water channel that is still open to the river gives the impression of slums and unpleasant odors. Domestic wastewater, especially those dealing with rivers, is discharged into rivers, not to mention garbage that has not been properly managed.

Facilities and infrastructure Settlement is one of the supports of the realization of a good settlement. Facilities and infrastructure also function as communal spaces, which is a space that accommodates various social activities that can be used by the community or community (Wijayanti,2,000) [11]. The existence of communal space will be a place for people to gather in doing activities together, integrating each other, discussing, deliberation, social activities, and others. There are several facilities and infrastructure owned by the residents of Kampung Aur for joint activities, including the following: 
Table 3. Supporting facilities and infrastructure

\begin{tabular}{|c|c|c|}
\hline No & Amenities & Information \\
\hline 1 & $\begin{array}{l}\text { The house of } \\
\text { worship also functions } \\
\text { as a landfill also } \\
\text { functions as a closed } \\
\text { communal space }\end{array}$ & $\begin{array}{l}\text { There are two houses of worship, the mosque in } \\
\text { Kampung Aur Dusun IV and neighborhood } 8 \text { near } \\
\text { the railroad street pawnshop, Catholic churches } \\
\text { scattered around Jl Katamso. Buddha temple. This } \\
\text { house of worship also functions as a closed } \\
\text { communal space such as meetings, discussions, etc. }\end{array}$ \\
\hline 2 & School & $\begin{array}{l}\text { Available, and the location is not too far from the } \\
\text { neighborhood. Still in one sub-district like SD, } 1 \\
\text { private university. }\end{array}$ \\
\hline 3 & Field / park & $\begin{array}{c}\text { Not available, settlement conditions are very } \\
\text { crowded }\end{array}$ \\
\hline 4 & Market & $\begin{array}{l}\text { Available, and the location is not too far from } \\
\text { residential areas.Still in one district }\end{array}$ \\
\hline 5 & $\begin{array}{l}\text { Hospital/clinic/ } \\
\text { postage. }\end{array}$ & $\begin{array}{c}\text { There are } 7 \text { Posyandu and clinics available in } \\
\text { this settlement. } \\
\text { And the service is still categorized as good }\end{array}$ \\
\hline 6 & Open public space & $\begin{array}{c}\text { Located in the yard of the house that functions as } \\
\text { a place to sell, and often used as a gathering } \\
\text { place for residents, the mosque yard becomes a } \\
\text { means for children to play. }\end{array}$ \\
\hline
\end{tabular}

Source: Analysis of secondary data, 2019.

From the table above it can be seen that the facilities and infrastructure available to support the completeness of Settlements are sufficiently available even though they are inadequate. Many people use the mosque as a place of worship as well as a place of deliberation, and the mosque yard as a children's playground. Besides that, many yards of houses are used as places to sell daily necessities and selling food which also functions as a place for people to gather to socialize. Family relations between residents are very close, they know each other, and help each other.

Based on the results of the research obtained through direct observation, interviews with residents, the Lurah and local RT and analysis of field data to obtain the characteristics of Settlement both social and physical, shows that there are major factors that make people in Kampung Aur reluctant to move or be relocated. These factors are among other things; 1) the length of time residents have lived in Kampung Aur which has been passed down from their parents and then passed on by their children which eventually became the basis for claiming their legal existence in agrarian, and this was also reinforced by the UN levies they paid to Country. 2) the location of Kampung Aur near and downtowns such as offices, restaurants, and others that are very supportive for the economic activities of citizens, 3) the high level of family ties between residents supported by similarity of origin/ethnicity, and a sense of common sense, so that many choose to remain in Kampung Aur, 4) adequate basic settlement 
services such as access to and out of villages, roads that connect between RT, clean water facilities that are already available, and electricity PLN 5) The existence of public facilities and infrastructure to strengthen relations between residents to care for each other, please help so as to strengthen the familial relationship between citizens.

Based on the aforementioned factors, Kampung Aur will remain a choice of citizens, although the Medan city government wishes to relocate residents, this has never been possible. This has been conveyed by the government to residents. According to information, the government had planned to organize the Settlement by making flats, but the residents wanted the arrangement without evicting or not in the form of flats. The desire of the government and citizens will never be met, so this is a dilemma for both parties. One side of the government has the authority to make the city environment comfortable and safe for all citizens, but on the other hand of course citizens should abide by the rules according to applicable government rules that the existence of improper settlements does not cause problems for the environment and the residents themselves such as flood hazards, because the riverbanks should be planted with trees as an antidote to abrasion and free from residential settlements/other buildings. Likewise with the suburbs of the railroad tracks which are the land of PJKA which can be evicted at any time.

\section{Conclusion}

Based on the findings and discussion of the results of research that have been carried out conclusions can be drawn as follows: (1) based on the social characteristics of the community, most of the people of Kampung Aur come from the Minang ethnic group, followed by Javanese with the main activity being private workers and traders, with a high school education level, (2) the location of the settlement is close to the main road Brigjen Katamso and there are many offices, restaurants and others so that many young people use this opportunity to become parking attendants and also as traders who do not need special expertise, so the location of Kampung Aur Settlement strongly supports community economic activities, (3) most of the inhabitants of Kampung Aur have lived for generations in the area of Kampung Aur, so the close family ties between them and the high level of concern have become one of the reasons for reluctance to move, (4) residents believe the status of home ownership that has been occupied for more than 20 years is legally valid according to the agrarian law even without a certificate, thus making people prefer to remain in Kampung Aur, (5) inadequate housing conditions, most types of nonpermanent buildings with one room plus a living room that is occupied by one family with 2-3 children at the same time, are not good enough for children's growth and development, especially vulnerable to drug trafficking, (6) settlements on the edge of the Deli river are flood-prone areas when the rainy season arrives, (7) the basic services of the Settlement are already quite good, such as PLN, clean water, and access to main roads or environmental roads which are already largely cemented, (8) the existence of public facilities and infrastructure strengthens the relationship between citizens to care for each other, please help so as to strengthen the familial relationship between residents, (9) most residents are reluctant to move / be relocated because their location is 
close to the city center, besides that the family ties between residents are very high, and (10) residents prefer the arrangement of the environment without displacing.

\section{References}

[1] Undang-Undang No. 1 Pasal 1 Ayat 13 tahun 2011 TentangPerumahandan KawasanPermukiman.

[2] Rahmadi, Deva Kurniawan. 2009. PermukimanBantaran Sungai: PendekatanPenataan Kawasan Tepi Air dalam Buletin Tata Ruang edisi ke-5, September - Oktober 2009, Pengembangan Wilayah PesisirdanTepi Air. Jakarta: Sekretariat Tim Pelaksana BKPRN.

[3] Badan Pusat Statistik Sumatera Utara, 2018.

[4] Pinem, M. 2011. PersebaranPermukimanKumuh di Kota Medan. Volume 3, Nomor 1. JurnalGeografi. UniversitasNegeri Medan.

[5] UN-Habitat. 1982. Survey of Slums and Squatter Settlements.Dublin :Tycooly International Publishing Ltd.

[6] Rindarjono, Mohammad Gamal. 2013. Slum Kajian Permukiman Kumuh Dalam Perspektif Spasial. Yogyakarta : Media Perkasa.

[7] Budiharjo, Eko. 2009. PerumahandanPermukiman di Indonesia. Semarang: P.T. Alumni.

[8] Budiharjo, Eko. 2009. PerumahandanPermukiman di Indonesia.Semarang: P.T. Alumni.

[9] Strauss, Anselm and Corbin, Juliet.1990. Basics of Qualitative Research : Grounded Theory Procedures and Techniques. Sage Publication.

[10] Keputusan Wali Kota Medan No.640 / 039.K / I / 205

[11] Wijayanti, S.2000. pola Setting RuangKomunal Interaksi Sosial(Tesis) Arsitektur UndidpSemarang. 